\title{
Corporate Governance Mechanisms and Performance of Public-Listed Family-Ownership in Malaysia
}

\author{
Haslindar Ibrahim (Corresponding author) \\ School of Management, Universiti Sains Malaysia \\ 11800 USM, Penang, Malaysia \\ Tel: 60-4-653-2894Ｅ-mail: haslindar@usm.my \\ Fazilah Abdul Samad \\ Faculty of Business \& Accountancy, Universiti Malaya \\ 50603 Kuala Lumpur, Malaysia \\ Tel: 60-19-225-2490 E-mail: mfazilah@um.edu.my
}

The research is financed by Incentive Grant, Universiti Sains Malaysia, Penang, Malaysia No 304/JPNP/600004.

\begin{abstract}
The study examines the relationship of corporate governance mechanisms and performance between family and non-family ownership of public-listed firm in Malaysia from 1999 through 2005 as measured by Tobin's Q, ROA and ROE. The findings show that on average, family ownership experiences a higher value than non-family ownership based on ROE. On the other hand, based on Tobin's Q and ROA, the study finds that firm value is lower in family than non- family ownership. In addition, the corporate governance mechanisms such as the board size, independent director and duality for family and non-family ownership has a strong significant influence on firm performance.
\end{abstract}

Keywords: Corporate governance, Family-ownership, Ownership structure

\section{Introduction}

The family controlled firm or family ownership is the most common form of business organization in the world. Family-owned or controlled businesses account for over 80 percent of all firms in the U.S. and families are present in one third of the S\&P 500 and hold nearly 18 percent of firms' equity stake (Anderson and Reeb, 2003). Other studies from different countries like Sraer and Thesmar (2006) in French, Favero, Giglio, Honorati, and Panunzi (2006) in Italy, Gursoy and Aydogan (2002) in Turkey, Mishra, Randoy and Jenssen (2001) in Norway, Yeh, Lee and Woidtke (2001) in Taiwan and Gorriz and Fumas (1996) in Spain, conduct research on the performance of family-controlled firms based on a sample of listed firms in their countries. The results show that family firms have superior performance compared to non-family firms.

Ownership structure has been widely debated since Berle and Means (1932). According to Jensen (2000), ownership structure is significant in determining firms' objectives, shareholders wealth and the disciplined of manager. Both managers and shareholders should have a single objective of maximizing firm value. The ownership structure can be grouped into widely held firms and firms with controlling owners or concentrated ownership. A widely held corporation does not have any owners with substantial control rights. Basically, firms with controlling owners are divided into four groups which are widely held corporations, widely held financial institutions, families and state categories (Claessens, Djankov, and Lang, 2000; La Porta, Lopez-De-Silanes, and Shleifer, 1999). La Porta et al. (1999) study the 20 largest publicly traded companies in the richest 27 countries worldwide. They find that most companies are private and that ownership of listed firms is highly concentrated, thereby highlighting family ownership as significant corporations.

According to the study of Claessens et al. (2000) on the separation of ownership and control in nine East Asian corporations (Hong Kong, Indonesia, Japan, South Korea, Malaysia, Philippines, Singapore, Taiwan and Thailand), Malaysia has the third highest concentration of control after Thailand and Indonesia. Family control in Malaysia increased from 57.7 percent to 67.2 percent as the cut off level of voting rights increased from 10 percent to 20 percent.

In Asia, various literature shows that family firms reflect a high performance in Taiwan, Australia, Hong Kong, Singapore, and mainland China (Filatotchev, Lien and Piesse, 2005; Chen, 2001; and La Porta et al., 1999). Names like Ayala Families, (Phillipines), Li Ka-Shing (Hong Kong) and Kyuk Ho Shin (South Korea) are well known among the family group companies. In Malaysia, names like Robert Kuok (Kuok Brothers), Lim Goh Tong and 
Quek Leng Chan are synonymous with Malaysian corporate industries. In other words, family firms seem to dominate the corporate world with prevalent performance.

In Malaysia, family ownership constitutes over 43 percent of the main board companies of the Bursa Malaysia (formerly known as the Kuala Lumpur Stock Exchange (KLSE)) from 1999 through 2005 yet studies examining the performance of family ownership are very limited specifically in the area of corporate governance. Thus, the study intends to investigate the impact of corporate governance mechanisms such as board size, independent director and duality on performance between family and non-family ownership in Malaysia. The results show that, on average, firm value of family-owned firms is lower than non family based on Tobin's Q and ROA. However, family ownership experiences a higher value than non-family ownership as measured by ROE. The findings find a strong relationship between firms with smaller boards and firm value for both family and non-family ownership. While family ownership needs less independent director as compared to non-family ownership. The firm value of family ownership is weaker but non-family ownership gains more profitability when duality exists on the board. This is consistent with the previous studies by Florackis and Ozkan (2004), McKnight and Mira (2003), and Jensen and Meckling (1976).

\section{Literature Review}

\subsection{Family-Ownership Scenario in Malaysia}

Various studies have been done on the effect of ownership structure and firm performance in Malaysia. Abdul Rahman (2006) indicates that many listed firms in Malaysia are owned or controlled by family and that these companies appear to be inherited by their own descendants. Since independence, most Malaysian companies are controlled by foreigners from European countries, particularly the U.K.

Jasani (2002) finds that Small and Medium Scale Enterprises (SME) are managed by the founder and anchored to the family in terms of funding and employment. Indeed, the firms are conducted by the founder with activities concentrating on trading, manufacturing and retailing. He finds that 59 percent, that is the majority of the businesses in Malaysia, are still managed by the founder while 30 percent are run by the second generation where the majority are the founder's children. The founder's reign is highlighted with 65 percent of them linked to the SME.

According to Gomez (2004), most of the Small and Medium Enterprises (SMEs) owners prefer their heirs to become professionals and do not encourage passing their businesses to them. Sometimes the SMEs founders reject joining the enterprise, which might cause the firms to be sold off or close down. It shows that the paradigm shift towards generation plays a significant direction on the firm's development. In other words, the prospects of family firms will be threatened.

Indeed, Claessens et al. (2000) also find that most concentrated firms in Malaysia are dominated by family founders and their descendants. Perhaps, older and smaller companies tend to be controlled by family instead of vice versa.

In Malaysia, the list of the 40 richest Malaysians 2009 is obviously dominated by family as issued by the Malaysian Business in February 2009 edition. From the list, 28 out of the 40 richest people are family based and account for 70 percent of the top 40. According to the top 40 list of Malaysia's richest people, Tan Sri Robert Kuok appears to dominate the chart and he was well ahead of his rivals. His outstanding wealth accounted for RM26.6 billion or 27.6 percent of the wealth of the 40 richest declining from RM58.1 billion in 2008, however no other tycoon is yet able to unseat him as the country's wealthiest individual (Singh, 2009).

\subsection{Corporate Governance Mechanisms and Firms Performance}

Denis and McConnell (2003) define corporate governance as the set of mechanisms, for both institutional and market based, that influence the self-interested controllers of a firm (those that make decisions regarding how the firm will be operated) to make decisions that maximize the value of the firm for its owners (the suppliers of capital). In other words, Shleifer and Vishny (1997) describe "Corporate governance deals with the ways in which suppliers of finance to corporations assure themselves of getting a return on their investment."

The influence of the board size and composition are significant to board involvement in corporate affairs. The board size and composition should be controlled since it may influence the impact of insiders and block ownership on firm's performance. Both the board size and composition could act as either a complement or substitute for ownership structure. Singh and Davidson III (2003) state that the size and composition of the board may reflect its ability to be an efficient guide and their findings show that firm performance is increased by smaller boards consistent with Hermalin and Weisbach (2003), Jensen (1993) and Lipton and Lorsh (1992).

Indeed, previous studies in several other countries also find a negative relationship between board size and firm performance. Mak and Yuanto (2002) examine the relationship between the size of the board and firm performance in Singapore and Malaysia, and find that board size is negative in relation to Tobin's Q. Similarly in Finland, 
Eisenberg et al. (1998) find evidence that there is a negative relationship between board size and profitability for small and medium size firms. The result is also consistent with Mishra et al.'s (2001) study on the corporate governance of family firms in Norway. Their findings showed that the board size has a negative significant coefficient indicating that firms with a smaller board size achieve higher q values. This is further supported by numerous other studies, which confirmed that large boards are not as effective as small boards (Lipton and Lorssch, 1992; Gladstein, 1984; Olson, 1982; and Jensen and Meckling, 1976).

Conversely, Pearce and Zahra (1991) and Pfeffer (1973) suggest that an increase in size of board and diversity may yield an advantage by building a network with the external environment and securing a broader resource platform, hence, creating a corporate identity. Adam and Mehran (2003) also find a positive and significant relationship between the size of the board and firm performance as measured by Tobin's Q. While, Brewer III et al. (2000) mention that there is no empirical evidence on the impact of the board size on bid premiums in the case of mergers and acquisitions.

Fama and Jensen (1983) explain that board outsiders could strengthen the firm's value by lending experience and monitoring services. Outside directors are supposed to be guardians of the shareholders' interests via monitoring. Hermalin and Weishbach (1991) and Coughlan and Schmidt (1985) support the argument that outside directors are more effective monitors and a critical disciplining device for managers. This evidence is further supported by McKnight and Mira (2003). They find a positive and significant relationship between outsiders' proportion and firm value as measured by Tobin's $Q$

However, Klein et al. (2004), Subrahmanyam et al. (1997), and Agrawal and Knoeber (1996) find that board independence is in fact negatively correlated with performance. This evidence is further supported by Weir and Laing (1999) and Yermack (1996) who find a negative relationship between the proportion of outside directors and firm performance. Haniffa and Hudaib (2006), Klein (1998), and Hermalin and Weishbach (1991) posit no significant relationship between performance and outsiders' proportion on the board of directors as measured by Tobin's $\mathrm{Q}$ and ROA.

Previous studies analyzing the impact of duality on firm performance have been mixed. Weir et al. (2002) find that duality has no role in enhancing firm performance in U.K firms and this result is similar with Dalton et al. (1998), Vafeas and Theodorou (1998) and Brickley et al. (1997).Haniffa and Hudaib (2006) find that the duality role is not significant in relation to firm value as measured by Tobin's Q. However, the duality is found to be significant in a negative direction with firm performance as measured by return on assets (ROA). This result implies that it is significant if the position of CEO and Chairman is held by a different person as recommended by the Malaysian Institute of Corporate Governance (MICG). This evidence is supported by McKnight and Mira (2003) who find that duality has a moderately strong and negative impact on quality values. In other words, firms where duality did exist performed poorly compared to those firms where the CEO did not occupy both positions.

On the other hand, Rechner and Dalton (1991) find that the firms where the CEO also serves as chairman have a higher ROE, ROI and profit margins. This result is consistent with previous studies ( $\mathrm{Pi}$ and Timme, 1993; and Donaldson and Davis, 1991). Boyd (1994) claims that role duality could increase firm performance. . This is because non duality dilutes the top management power and increases the probability of conflict between the board of directors and management.

\section{Data and Methodology}

As at 31 December 1999, a total of 474 companies were listed on the main board of the Bursa Malaysia and all financial companies were omitted from the sample because of differences in regulatory requirements. In addition, the study excluded the companies which fail to comply with any obligations under Practice Note such as Practice Note 4 (PN4) and Practice Note 17 (PN17) and also companies with incomplete data. As a result, we selected 2030 observations for 290 companies across seven years from 1999 to 2005 as our sample (Note 1).

This study uses secondary data regarding ownership structure and financial indicators for the period of 1999 to 2005 . The data was taken from the annual reports of company and financial databases such as Worldscope, Datastream, and Perfect Analysis. Information on corporate governance mechanisms such as board size, independent directors, and duality were collected from the Companies Annual Reports. This information was obtained manually by calculating the number of directors on the board, the number of independent directors on the board, and determining the duality role of CEO and chairman of the company for the years 1999 to 2005 .

In Malaysia, information on lists of family ownership is unavailable and not recorded. Therefore, this pioneering study had to determine by using the name of board members as the procedure to determine the family ties or relationship. The family ties, which are considered to be family members, include anyone who has a blood relationship and also family-in-law. In addition, this study uses the fraction of equity stake held by all family 
members as being at least 20 percent or more. The fraction of equity ownership is calculated by referring to the direct and indirect shareholdings of the family members extracted from the Company Annual Reports. This data collection is considered to be appropriate since it has also been adopted by previous studies (Sraer and Thesmar, 2006; Favero et al., 2006; Anderson and Reeb, 2003; La Porta et al., 1998; and Berle and Means, 1932).

Several control variables used to control for companies characteristics such as firm size, firm risk and firm age. Firm size is the natural log of total asset (Inasset) of the company. We also control for companies debt ratio as a firm leverage (Lev) by calculating total debt over total asset of the company. Firm age (Age) is measured as the number of years since the company is incorporated.

The study used market measure such as Tobin's Q which is computed as the ratio of the market capitalization plus total debt divided by total asset of the company. Also, accounting measures such as Return on Assets (ROA) which is the ratio of net income divided by the total assets and Return on Equity (ROE), the ratio of the net income divided by the shareholder's equity as a performance measurement. These performance measures have been widely used as proxies for firm performance (Sraer and Thesmar, 2006; Favero et al., 2006; Haniffa and Hudaib, 2006; Anderson and Reeb, 2003). Furthermore, the study uses the Fixed effects approach for the model of the study thus, the following model has been developed to analyze the relationship between corporate governance and performance for both family and non-family ownership.

Firm Value $=\alpha_{0}+\beta_{1}$ Lev $+\beta_{2}$ Age $+\beta_{3}$ Lnasset $+\beta_{4}$ Bsize $+\beta_{5}$ OutDir $+\beta_{6}$ Duality $+\varepsilon$

\section{Results and Discussion}

\subsection{Descriptive Statistics}

Table 1 presents the descriptive statistics for full and individual sample for family and non family ownership in Malaysia. It reports the values of means and the t-statistics that test the differences of means of these variables between family and non family. The descriptive statistics show an average value of leverage (the proportion of total debt to total asset) for the full sample of 26.0 percent while the leverage ratio for family and non-family are 25.6 percent and 26.2 percent respectively. The results show that the family ownership uses less debt, however, family firms do not appear to use debt differently than non-family, which is consistent with the findings of Sraer and Thesmar (2006), Anderson and Reeb (2003) and Mishra et al. (2001)..

The average of firm age in all samples of the study is nearly 30 years old and is not statistically significant different between family and non-family ownership in this sample. Even though there is no significant difference in age between family and non-family, family firms are younger than non-family firms ( 29 versus 30 years old) consistent with Amit and Villalonga (2006), Sraer and Thesmar (2006) and Anderson and Reeb (2003).

The descriptive statistics also show that an average value of total assets for all firms amounts to RM1,936.36 million. In relation to ownership structure, on average, family ownerships are smaller than non-family ownership but still of large size with average total assets of RM1,700.71 million relative to RM2,114.88 million, and statistically insignificantly different in mean. This result is similar with other empirical studies on family and non-family firms such as Sraer and Thesmar (2006), Favero et al. (2006), Amit and Villalonga (2006), Anderson and Reeb (2003) and Mishra et al. (2001).

The mean value of market capitalization for all firms amounts to RM1,100.95 million with the highest (lowest) level being RM33,611.57 million (RM27.56 million). In comparing the average value of market capitalization between family and non-family ownership, the results show that non-family has RM1,326.39 million more market value than family, which amounts to RM803.38 million. However, this result shows that there is no evidence of statistically significant differences in means for risk or leverage, age, total assets and market capitalization between family and non-family $(\rho>0.01)$.

Market measures as indicated by Tobin's q shows that non-family ownership have greater valuations than family ownership and significant at 1 percent level. By using ROA, family ownership also has lower value than non-family but insignificant difference in mean. However, with respect to ROE, family ownership experiences higher value than non-family ownership but statistically insignificant difference in mean.

For corporate governance structure, we found that board size for full sample, family and non family ownership is similar with an average of 8 persons on board. However, there is no difference in mean for board size between family and non family ownership. However, independent director shows a significant difference in mean between family and non-family. The independent directors are more common in non family than family ownership. The frequency of the duality shows that only 6.5 percent of the samples have not separated the role of chairman and $\mathrm{CEO}$ on the board and significant difference in mean for duality between family and non family.

Table 2 presents the correlation matrix for the dependent and independent variables of the study. Firm value as measured by Tobin's Q and ROA appears to bear a negative and positive relationship to board size and a positive 
and negative relationship to independent directors of the company. The results are consistent with Haniffa and Hudaib's (2006) study on corporate governance and performance of Malaysian listed companies. In addition, family ownership presence shows that there is a significantly negative relationship with Tobin's Q and the independent directors and significantly positively related to duality. This study finds a negative 23.5 percent correlation between independent director and family ownership, which is quite similar to a negative 36 percent in Mishra et al's (2001) study on Norwegian firms.

Furthermore, family ownership is insignificantly negatively correlated to the following variables: ROA, firm leverage (total debt to total asset), firm size, firm age and board size. With respect to the relationship between family ownership and board size, this result is inconsistent with Mishra et al. (2001) and Yermack's (1996) study on Norwegian and U.S family firms respectively. However, board size is quite highly significantly positively correlated to firm size and significantly negatively correlated to the firm age indicating that as the size of the firm becomes larger, the number of directors on the board also increases.

\subsection{Corporate Governance Mechanisms and Firm Performance}

This study has done an analysis on the corporate governance mechanisms to see their influence on firm performance, focusing on the ownership variable of family and non-family firms. Indeed, the study uses Tobin's Q, ROA and ROE as performance measures to evaluate the firm performance and the results are tabulated in Table 3, Table 4 and Table 5 respectively. The study finds that governance mechanisms such as board size, independent directors and duality have a significant effect on firm performance. Generally, board size of public listed companies in Malaysia is found to be significantly negatively related to Tobin's Q and ROE. This result is consistent with Haniffa and Hudaib (2006) and Mak and Yuanto (2002) who conducted a similar research on Malaysian listed companies and is also supported by other studies (Singh and Davidson III, 2003; Hermalin and Weisbach, 2003; Mishra et al., 2001). It implies that companies with a small board of directors accomplish higher values in the capital markets and are also more profitable than their counterparts with a large board of directors. However, board size is found to have a positive but not significant relationship to ROA for all samples of companies, which is supported by previous studies (Haniffa and Hudaib, 2006 and Adam and Mehran, 2003) ).

By looking at the individual ownership of family and non-family, both groups show a significantly negative relationship between board size and firm performance based on Tobin's Q and ROE. It indicates that smaller boards bring superior performance to companies. Concerning family ownership, this finding is consistent with Mishra et al. (2001) and Yermack (1996) who suggest that small boards are common in family firms as firms can be managed effectively because of the interrelationship between board members that facilitates quick decision making. Based on the ROA, both groups are not significant in relation to board size. In Malaysia, the Malaysian Code of Corporate Governance (MCCG) does not provide any guidance regarding the size of the boards in its code. Indeed, the companies might adjust or change board size in response to past performance as suggested by Gilson (1990) and Hermalin and Weisbach (1988).

With respect to independent directors, the study finds no significant relationship between the proportion of independent directors and performance based on Tobin's Q, and ROE for all firms and consistent with Haniffa and Hudaib (2006) and Weir et al. (2002). According to Hermalin and Weisbach (2003), a higher proportion of outside directors does not directly lead to superior performance, but it is good in decision making, which is related to executive remuneration, CEO turnover, and also acquisitions. However, the study finds the proportion of outside directors of all firms is found to be statistically significantly positively related to ROA only, suggesting that directors may stabilize and moderately improve a firm's profitability.

Interesting results are found between family and non-family ownership concerning the relationship between outside directors and performance. For family ownership, the results show a significantly negative relationship between the fraction of outside directors and firm performance based on ROA and ROE. The results are supported by Anderson and Reeb (2003), Mishra et al. (2001), Subrahmanyam et al. (1997), and Agrawal and Knoeber (1996). It implies that firm performance is decreased as outside directors are added to the board. More specifically, family firms may require a prudent balance between the objectivity of independent directors and the interests of family directors in order to pursue family members' interest.

The representation of outside directors or board independents does not improve corporate governance for family firms (Mishra et al., 2001). Based on recent studies, family values like altruism, trust and paternalism can deliver a commitment towards future success $(\mathrm{Wu}, 2001)$. For family firms, the expropriation of wealth and nepotism are kept at bay by the need for success in a competitive business. Perhaps, the need for outside directors decreases when the commitment of inside directors, who know the company very well, benefit the firm. According to Mishra et al. (2001), board members in family firms are perceived less as a governing mechanism and more as a top level strategy 
group. Indeed, Kang (1998) explains that family members serve as active monitors of their managers and the information flow between managers and family members serve as a control mechanism. In other words, the decisions made by managers are eventually justified and have mutual agreement with the owners.

In contrast, firms with non-family ownership have a significant positive relationship between the fraction of independent directors and performance based on Tobin's Q, ROA and ROE. This evidence is consistent with the view that outside directors improve board effectiveness and firm performance because of their efficiency in monitoring managers (Adams and Mehran, 2003). It indicates that non-family ownership prefers a higher presence of independent directors who could bring in their prestige, expertise and contacts to the firms. Additionally, outside directors could influence the quality of decisions and thoughtfulness in providing a strategic direction for the companies (Pearce and Zahra, 1992).

The role of duality is one of the corporate governance mechanisms and previous studies have raised this issue due to their belief that duality could make a difference to corporate governance and performance (Anderson and Anthony, 1986; and Alibrandi, 1985). According to Dahya, Lonie, and Power (1996) and Anderson and Anthony (1986), the duality role could assist the CEO in creating a good strategic vision for the firm in order to achieve its objectives, with minimal board interference. Thereby enhancing decision making and creating stability and continuity for the firm leading to superior firm performance.

However, generally, this study finds that duality for all firms is not significantly related to firm performance as measured by Tobin's Q and ROE. Hence, this finding is consistent with Haniffa and Hudaib (2006), Weir et al. (2002) and Vafeas and Theodorou (1998). It implies that there is no significant impact on firm value or decision making when someone holds both the CEO and chairman position. But, as measured by ROA, duality of all firms is found to be significantly negatively related, which is similar with the findings of Haniffa and Hudaib (2006) for a similar study in Malaysia. This evidence is also supported by Jensen (1986) who suggests that it gives too much power to someone holding two top positions and thereby allows decisions to be based on their personal interest with a consequent drop in firm performance. Moreover, it is better to separate the two roles in order to make sure that the top leadership of the firms have a proper check and balance as suggested by the MCCG.

The duality role of firms with family ownership is found to be significantly negatively related to Tobin's Q, ROA and ROE, which is consistent with Haniffa and Hudaib (2006) and McKnight and Mira (2003). It suggests that the existence of a duality role on the board could lead to poor performance compared to firms where both positions are separated.

In contrast, duality in firms with non-family ownership is significantly positively related with ROA and ROE. This finding is confirmed by Sridharan and Marsinko (1997) and Rechner and Dalton (1991) who find that firms with the existence of a duality role experience higher profitability and may also avoid some costs of conflict between the CEO and the board by having strong consistent leadership at the top. In addition, when more power is held by one person it may lead to better decisions and directly improve firm performance (Rechner and Dalton, 1991; Donaldson and Davis, 1991).

\section{Conclusion}

Our main objective in this study is to investigate the relationship between corporate governance and firm performance between family and non family ownership. The findings of the study reveal that, on average, firm value is lower in family ownership than non-family ownership and shows a significant difference only as measured by Tobin's Q. However, family ownership shows a higher value than non-family ownership based on ROE. Therefore, this evidence further confirms that family firms basically invest a high share of their assets in a certain firm, which might then subsequently invest in lower-risk-lower-return businesses where the return is less profitable (Mohd. Sehat and Abdul Rahman, 2005). Furthermore, family ownership is basically concerned with family interest and the survival of the firm as family firms tend to be small and risk averse.

We also find a strong relationship between firms with smaller boards and firm value suggesting that small board size could be a good and superior corporate governance mechanism for firms to improve performance. Furthermore, the study provide significant evidence that representation of independent directors is viewed differently by family and non-family ownership. The representation of independent directors in family firms does not improve firm performance and basic family values like altruism, trust and paternalism can deliver a commitment towards future success. Conversely, non-family ownership needs more independent directors to counsel and monitor the company. This strong evidence implies that a higher presence of independent directors in a non-family owned firm could improve the firm's value by bringing in their expertise and contacts to the firm. Generally, the relationship between the duality role and performance for all Malaysian listed firms is not significant, which is consistent with Haniffa and Hudaib (2006), but the study discovers different results by focusing on different types of ownership. The study 
finds that the firm value of family ownership is weaker when a duality role exists, however, non-family ownership experience higher profitability when the CEO also serves as chairman of the board. In conclusion, the research findings imply that family ownership is valuable as well as non-family ownership and significant findings also show that family ownership is governed differently than non-family ownership.

\section{References}

Abdul Rahman, R. (2006). Effective Corporate Governance, $1^{\text {st }}$ edition, University Publication Centre (UPENA), Uitm, Shah Alam, Malaysia.

Adams, R. \& Mehran, H. (2003). Is Corporate Governance Different for Bank Holding Companies?, Working Paper, Federal Reserve Bank of New York.

Agrawal, A. \& Knoeber, C.R. (1996). Firm Performance and Mechanisms to Control Agency Problems Between Managers and Shareholders. Journal of Financial and Quantitative Analysis, 31, 377-397.

Alibrandi, J.F. (1985). A CEOs Dream Board. in E. Nattar and M. Ball (eds). Handbook for Corporate Directors, New York: McGraw-Hill, 23.1-23.5.

Amit, R. \& Villalonga, B. (2006). How Do Family Ownership, Control, and Management Affect Firm Value?. Journal of Financial Economics, 80(2), 385-417.

Anderson, C.A. \& Anthony, R.N., (1986). The New Corporate Directors, New York: John Wiley and Sons.

Anderson, R.C. \& Reeb, D.M. (2003). Founding-Family Ownership and Firm Performance: Evidence from the S\&P 500. The Journal of Finance, 58(3),1301-1328.

Berle, A. \& Means, G. (1932). The Modern Corporation and Private Property, MacMillan, New York, N.Y.

Boyd, B. (1994). Board Control and CEO Compensations. Strategic Management Journal, 15, 335-344.

Brewer III, E. Jackson III, W. \& Jagliani, J. (2000). Impact of Independent Directors and the Regulatory Environment on Bank Merger Prices: Evidence from Takeover Activity in the 1990s, Working Paper 2000-31, Federal Reserve Bank of Chicago.

Brickley, J., Coles, J.L. \& Jarrell, G. (1997). Leadership Structure: Separating the CEO and Chairman of the Board. Journal of Corporate Finance, 3,189-220.

Chen, M.F. (2001). Inside Chinese Business: A Guide for Managers Worldwide, Boston: Harvard Business School Press.

Claessens, S., Djankov, S. \& Lang, L.H.P. (2000). The Separation of Ownership and Control in East Asian Corporation. Journal of Financial Economics, 58, 81-112.

Coughlan, A. \& Schmidt, R. (1985). Executive Compensation, Management Turnover, and Firm Performance: An Empirical Investigation. Journal of Accounting and Economics, 7, 43-66.

Dahya, J., Lonie, A.A. \& Power, D.M. (1996). The Case for Separating the Roles of Chairman and CEO: An Analysis of Stock Market and Accounting Data. Corporate Governance, 4, 71-77.

Dalton, D.R., Daily, C.M., Johnson, J.L., \& Ellstrand (1998). Number of Directors and Financial Performance: A Meta-Analysis. Academy Management Journal, 42, 674-676.

Dennis, D. \& McConnell, J.J. (2003). International Corporate Governance. Journal of Financial and Quantitative Analysis, 38, 1-36.

Donaldson, L. \& Davis, J. H. (1991). Stewardship Theory or Agency Theory: CEO Governance and Shareholder Returns Australian Journal of Management, 16 (1), 49-95.

Eisenberg, T., Sundgren, S., \& Wells, M. (1998). Larger Board Size and Decreasing Firm Value in Small Firms. Journal of Financial Economics, 48, 35-54.

Fama, E.F. \& Jensen, M.C. (1983). Separation of Ownership and Control. Journal of Law and Economics, 26 (June), 301-325.

Favero, C.A., Giglio, S.W., Honorati, M., \& Panunzi, F. (2006). The Performance of Italian Family Firms. ECGI Working Paper No. 127/2006, http://ssrc.com/abstract_id=918181.

Filatotchev, I., Lien, Y-C. \& Piesse, J. (2005). Corporate Governance and Performance in Publicly Listed, Family-Controlled Firms: Evidence from Taiwan. Asia Pacific Journal of Management, 22 (3), 257-283.

Florackis, C. \& Ozkan A. (2004). Agency Costs and Corporate Governance Mechanisms: Evidence for UK Firms. Working Paper, University of York, UK. 
Gilson, S. (1990). Bankruptcy, Board, Banks, and Blockholders: Evidence on Changes in Corporate Ownership and Control When Firms Default. Journal of Financial Economics, 27, 355-387.

Gladstein, D.J. (1984). Groups in Context: A Model of Task Group Effectiveness. Administrative Science Quarterly, 29, 499-517.

Gomez, E.T. (2004). De-Essentialising Capitalism': Chinese Networks and Family Firms in Malaysia. NIASnytt, Vol 3, pp. 8-10.

Gorriz, C.G. \& Fumas, V.S. (1996). Ownership Structure and Firm Performance: Some Empirical Evidence from Spain. Managerial and Decision Economics, 17, 575-586.

Gursoy, G. \& Aydogan, K. (2002). Equity Ownership, Risk Taking and Performance: An Empirical Investigation in Turkish Listed Companies. Emerging Markets Finance and Trade, 38(6), 6-25.

Haniffa, R. \& Hudaib, M. (2006). Corporate Governance Structure and Performance of Malaysian Listed Companies. Journal of Business Finance and Accounting, 33 (7-8), 1034-1062

Hermalin, B.E. \& Weisbach, M.S. (1988). The Determinants of Board Composition. Rand Journal of Economics, 19 (4), 589-606.

Hermalin, B.E. \& Weisbach, M.S. (1991). The Effects of Board Composition and Direct Incentives on Firm Performance.Financial Management, 101-112.

Hermalin, B.E. \& Weisbach, M.S. (2003). Boards of Directors as an Endogenously Determined Institution: A Survey of the Economic Literature. Economic Policy Review, April, 7-25.

Jasani, N.K. (2002). Malaysia's Family Businesses: The Family \& The Business International Survey Report. Shamsir Jasani Grant Thorton \& Malaysian Institute of Management, 1-8.

Jensen, M.C., (1993). The Modern Industrial Revolution, Exit, And The Failure Of Internal Control Systems. Journal of Finance, 43 (3), 831-880.

Jensen, M.C. (2000). A Theory of the Firm: Governance, Residual Claims, and Organizational Forms, Harvard University Press, Cambridge.

Jensen, M.C. \& Meckling, W.H. (1976). Theory of the Firm: Managerial Behavior, Agency Costs, and Ownership Structure Journal of Financial Economics, 3 (4), 305-360.

Klein, A. (1998). Affiliated Directors: Puppets Of Management Of Effective Directors?, Working Paper, New York University.

Klein, P., Shapiro, D.M. \& Young, J. (2004). Board Independence and the Family-Owned Firm, Canadian Investment Review, 17(3), 8-13.

La Porta, R., Lopez-De-Silanes, F., \& Shleifer, A. (1999). Corporate Ownership Around the World. The Journal of Finance, 54 (2), 471-517.

Lipton, M. \& Lorsch, J. (1992). A Modest Proposal for Improved Corporate Governance. Business Lawyer, 48, 59-77.

Mak, Y.T. \& Yuanto, K. (2002). Size Really Matters: Further Evidence on the Negative Relationship between Board Size and Firm Value, Working Paper, National Univ. of Singapore .

McKnight, P.J. \& Mira, S. (2003). 'Corporate Governance Mechanisms, Agency Costs and Firm Performance in UK Firms,' http://ssrn.com/abstract=460300.

Mishra, C.S., Randoy, T. and Jenssen, J.I. 2001. The Effect of Founding Family Influence on Firm Value and Corporate Governance. Journal of International Financial Management and Accounting, 12 (3), 235-259.

Mohd Sehat, R. \& Abdul Rahman, R. (2005). Ownership of the Firm and Corporate Value, Working Paper Faculty of Accountancy, Universiti Teknologi MARA, Shah Alam, Selangor.

Olson, M. (1982). The Rise and Decline of Nations: Economic Growth, Stagflation, and Social Rigidities, Yale University Press, New Haven, CT.

Pearce, J.A. \& Zahra, S.A. (1991). The Relative Power of CEOs and Boards of Directors: Association with Corporate Governance. Strategic Management Journal, 12, 135-188.

Pearce, J.A. \& Zahra, S.A. (1992). Board Composition from a Strategic Contingency Perspective. Journal of Management Studies, 29 (4), 411-438.

Pfeffer, J. (1973). Size Composition and Functions of Hospital Boards of Directors: A Study of Organization-Environment Linkage. Administrative Science Quarterly, 18, 349-364. 
Pi, L. \& Timme,S.G. (1993). Corporate Control and Bank Efficiency. Journal of Banking Finance, 17, 515-530.

Rechner, P. L. \& Dalton, D. R. (1991).CEO Duality and Organizational Performance: A Longitudinal Analysis. Strategic Management Journal, 12 (2), 155-178.

Shleifer, A. \& Vishny, R. (1997). A Survey of Corporate Governance Journal of Finance, 52 ( 2), 737-782

Singh, B. (2009). Malaysia's 40 Richest, Malaysian Business, February $16^{\text {th }}-29^{\text {th }}, 2009,16$.

Singh, M. \& Davidson III, W.N. (2003). Agency Costs, Ownership Structure and Corporate Governance Mechanisms. Journal of Banking and Finance, 27, 793-816.

Sraer, D. \& Thesmar, D. (2006). Performance and Behavior of Family Firms: Evidence from the French Stock Market, ECGI Working Paper No. 130/2006, http://ssrn.com/abstract_id=925415.

Sridharan, U. V \& Marsinko, A. (1997). CEO Duality in the Paper and Forest Products Industry. Journal of Financial and Strategic Decisions, 10 (1), 59-65.

Subrahmanyam, V.N., Rangan N., \& Rosenstein, S. (1997). The Role of Outside Directors In Bank Acquisitions. Financial Management, 26, 23-36.

Vafeas, N. \& Theodorou, E. (1998). The Association between Board Structure and Firm Performance in the U.K.. British Accounting Review, 30, 383-407.

Weir, C. \& Laing, D. (1999). Governance Structure, Size and Corporate Performance in UK Firms. Management Decision, 37 (5\&6), 457-464.

Weir, C., Laing, D., \& McKnight, P.J. (2002). Internal and External Government Mechanisms: Their Impact on the Performance of Large UK Public Companies. Journal of Business Finance and Accounting, 19 (5\&6), 579-611.

$\mathrm{Wu}$, Z. (2001). Altruism and the Family Firm, Some Theory, Unpublished Master's Thesis, Department of Economics, University of Calgary, Canada.

Yeh, Y.H., Lee, T.S. \& Woidtke, T. (2001). Family Control and Corporate Governance: Evidence from Taiwan International Review of Finance, 2 (1/2), 21-48.

Yermack, D. (1996). Higher Market Values of Companies with a Small Board of Director. Journal of Financial Economics, 40 (2), 185-211.

\section{Notes}

Note 1. PN4 and PN17 are the criteria and obligations pursuant to paragraph 8.14 and $8.14 \mathrm{c}$ respectively of the listing requirements in the Bursa Malaysia. Both PN4 and PN17 occur when the firms having financial difficulties. PN4 is further amended to PN17 and effective on 3 January 2005.

Table 1. Descriptive Statistics for Full Sample, Family, and Non Family for Year 1999 to 2005

\begin{tabular}{|c|c|c|c|c|c|}
\hline \multirow[t]{2}{*}{ Variables } & \multicolumn{2}{|c|}{$\begin{array}{c}\begin{array}{c}\text { Full Sample } \\
(\mathrm{N}=290)\end{array} \\
\end{array}$} & \multirow{2}{*}{$\begin{array}{c}\text { Family }(\mathrm{N}=125) \\
\text { Mean } \\
\end{array}$} & \multirow{2}{*}{$\begin{array}{c}\begin{array}{c}\text { Non Family } \\
(\mathrm{N}=165)\end{array} \\
\text { Mean }\end{array}$} & \multirow[t]{2}{*}{$\begin{array}{l}\text { t-statistics of } \\
\text { Differences }\end{array}$} \\
\hline & Mean & Std Dev & & & \\
\hline $\begin{array}{l}\text { Firms Characteristics } \\
\text { Firm Leverage } \\
\text { Firm Age (years) } \\
\text { Firm Size (total asset) ('000) } \\
\text { Market Capitalization ('000) }\end{array}$ & $\begin{array}{l}0.260 \\
29.617 \\
1,936,356.6 \\
1,100,952.6\end{array}$ & $\begin{array}{l}0.255 \\
17.798 \\
4,517,151.2 \\
3,189,398.3 \\
\end{array}$ & $\begin{array}{l}0.256 \\
29.2 \\
1,700,708.6 \\
803,379.0\end{array}$ & $\begin{array}{l}0.262 \\
29.8 \\
2,114,877.7 \\
1,326,387.1\end{array}$ & $\begin{array}{l}-0.199 \\
-0.280 \\
-0.773 \\
-1.524 \\
\end{array}$ \\
\hline $\begin{array}{l}\text { Performances Characteristics } \\
\text { Market Measures: } \\
\text { Tobin's Q } \\
\text { Accounting Measures: } \\
\text { Return on Assets (ROA) } \\
\text { Return on Equity (ROE) } \\
\end{array}$ & $\begin{array}{l}0.948 \\
0.032 \\
0.013 \\
\end{array}$ & $\begin{array}{l}0.991 \\
0.249 \\
0.927 \\
\end{array}$ & $\begin{array}{l}0.788 \\
0.026 \\
0.087 \\
\end{array}$ & $\begin{array}{l}1.069 \\
0.036 \\
-0.042 \\
\end{array}$ & $\begin{array}{l}-2.697 * \\
-0.350 \\
1.175 \\
\end{array}$ \\
\hline $\begin{array}{l}\text { Governance (Board } \\
\quad \text { Structure) Characteristics } \\
\text { Board Size } \\
\text { Independent Director }\end{array}$ & $\begin{array}{l}8 \\
0.385 \\
\end{array}$ & $\begin{array}{l}1.875 \\
0.088 \\
\end{array}$ & $\begin{array}{l}8 \\
0.361 \\
\end{array}$ & $\begin{array}{l}8 \\
0.403 \\
\end{array}$ & $\begin{array}{l}0.373 \\
-\mathbf{4 . 3 4 1 *}\end{array}$ \\
\hline $\begin{array}{l}\text { Percentage of Duality in sample: } \\
\text { Full Sample } \\
\text { Family } \\
\text { Non-Family }\end{array}$ & $\begin{array}{l}\text { Non-Duality (0) } \\
93.5 \% \\
87.5 \% \\
98.2 \%\end{array}$ & $\begin{array}{l}\text { Duality (1) } \\
6.5 \% \\
12.5 \% \\
1.8 \%\end{array}$ & & & \\
\hline
\end{tabular}

* Significant at 0.01 level 
Table 2. Pearson's Correlation Matrix

\begin{tabular}{|c|c|c|c|c|c|c|c|c|c|c|}
\hline Variables & $\mathbf{Q}$ & ROA & ROE & LEV & $\begin{array}{c}\text { LN- } \\
\text { ASSET }\end{array}$ & AGE & BSIZE & OUTDIR & DUALITY & FAMILY \\
\hline $\mathbf{Q}$ & 1 & & & & & & & & & \\
\hline ROA & 0.029 & 1 & & & & & & & & \\
\hline ROE & 0.084 & $0.386^{* *}$ & 1 & & & & & & & \\
\hline LEV & $0.446^{* *}$ & $-0.143^{*}$ & -0.089 & 1 & & & & & & \\
\hline LNASSET & $-0.281 * *$ & -0.039 & 0.025 & -0.021 & 1 & & & & & \\
\hline AGE & 0.112 & -0.051 & 0.002 & 0.058 & -0.019 & 1 & & & & \\
\hline BSIZE & -0.064 & 0.038 & 0.066 & $-0.145 *$ & $0.378^{* *}$ & $-0.150 *$ & 1 & & & \\
\hline OUTDIR & 0.007 & -0.012 & -0.027 & 0.100 & -0.019 & $0.215^{* *}$ & $-0.400 * *$ & 1 & & \\
\hline DUALITY & 0.004 & -0.027 & 0.003 & 0.038 & 0.108 & -0.005 & 0.003 & -0.003 & 1 & \\
\hline FAMILY & $-0.134 *$ & -0.021 & 0.068 & -0.010 & -0.009 & -0.009 & 0.016 & $-0.235^{* *}$ & $0.261^{* *}$ & 1 \\
\hline
\end{tabular}

** significant at 0.01 level (2-tailed).

* significant at the 0.05 level (2-tailed)

Table 3. The Fixed Effect Models by Using Tobin's Q

\begin{tabular}{|l|ll|ll|lc|}
\hline \multicolumn{1}{|c|}{ Variables } & \multicolumn{2}{|c|}{ Full Sample (N=290) } & \multicolumn{2}{c|}{ Family $(\mathbf{N = 1 2 5 )}$} & \multicolumn{2}{c|}{ Non Family (N=165) } \\
\hline Intercept & 4.904 & $(27.626)^{* * *}$ & 3.047 & $(16.101)^{* * *}$ & 5.563 & $(19.694)^{* * *}$ \\
Firm Leverage & 0.655 & $(27.988)^{* * *}$ & 0.673 & $(17.862)^{* * *}$ & 0.596 & $(18.518)^{* * *}$ \\
Firm Age (years) & -0.018 & $(-13.524)^{* * *}$ & -0.015 & $(-8.984)^{* * *}$ & -0.024 & $(-10.097)^{* * *}$ \\
Firm Size (lnasset) & -0.262 & $(-20.186)^{* * *}$ & -0.139 & $(-10.510)^{* * *}$ & -0.289 & $(-14.359)^{* * *}$ \\
BSize & -0.006 & $(-2.274)^{* *}$ & -0.013 & $(-3.614)^{* * *}$ & -0.008 & $(-1.907)^{*}$ \\
OutDir & 0.003 & $(0.071)$ & -0.026 & $(-0.551)$ & 0.102 & $(1.717)^{*}$ \\
Duality & -0.020 & $(-0.890)$ & -0.044 & $(-1.753)^{*}$ & 0.049 & $(0.731)$ \\
\hline Observation & 2030 & & 875 & & 1155 & \\
\hline $\mathbf{R}^{2}$ & 0.888 & & 0.850 & & 0.895 & \\
\hline Adj. R & 0.869 & & 0.824 & & & \\
\hline F-stat (p-value) & $46.560(0.000)$ & $32.551(0.000)$ & & \\
\hline
\end{tabular}

*** Significant at the $1 \%$ level. ** Significant at the $5 \%$ level. * Significant at the $10 \%$ level.

$\mathrm{t}$-statistics are in parentheses

Table 4. The Fixed Effect Models by Using Return on Asset (ROA)

\begin{tabular}{|c|c|c|c|c|c|c|c|c|}
\hline \multirow{3}{*}{$\begin{array}{l}\quad \text { Variables } \\
\text { Intercept } \\
\text { Firm Leverage }\end{array}$} & \multicolumn{2}{|c|}{ Full Sample $(\mathrm{N}=290)$} & \multicolumn{2}{|c|}{ Family (N=125) } & \multicolumn{4}{|c|}{ Non Family ( $N=165)$} \\
\hline & 0.384 & $(7.066)^{* * *}$ & 0.098 & $(2.341)^{* *}$ & 0.342( & )*** & & \\
\hline & -0.150 & $(-17.868)^{* * *}$ & -0.121 & $(-11.017)^{* * *}$ & -0.187 & $(-14.576)^{* * *}$ & -0.004 & $(-4.857)^{* * *}$ \\
\hline Firm Age (years) & -0.002 & $(-4.290)^{* * *}$ & 0.0001 & $(0.235)$ & -0.013 & $(-1.946)^{*}$ & & \\
\hline Firm Size (lnasset) & -0.021 & $(-4.881)^{* * *}$ & -0.002 & $(-0.448)$ & 0.001 & $(0.930)$ & & \\
\hline BSize & 0.001 & $(1.473)$ & -0.001 & $(-0.795)$ & 0.052 & $(2.649)^{* * *}$ & & \\
\hline OutDir & 0.044 & $(3.953)^{* * *}$ & -0.039 & $(-3.497)^{* * *}$ & 0.050 & $(2.156)^{* *}$ & & \\
\hline Duality & -0.018 & $(-2.432)^{* *}$ & -0.024 & $(-2.169)^{* *}$ & & & & \\
\hline Observation & 2030 & & 875 & & 1155 & & & \\
\hline $\mathbf{R}^{2}$ & 0.760 & & 0.716 & & 0.754 & & & \\
\hline Adj. $\mathbf{R}^{2}$ & 0.719 & & 0.666 & & 0.712 & & & \\
\hline F-stat (p-value) & 18.601 & & 14.434 & & 17.752 & & & \\
\hline
\end{tabular}

*** Significant at the $1 \%$ level. ** Significant at the $5 \%$ level. * Significant at the $10 \%$ level.

$t$-statistics are in parentheses 
Table 5. The Fixed Effect Models by Using Return on Equity (ROE)

\begin{tabular}{|c|c|c|c|c|c|c|}
\hline \multirow{2}{*}{$\begin{array}{l}\text { Variables } \\
\text { Intercept }\end{array}$} & \multicolumn{2}{|c|}{ Full Sample $(\mathrm{N}=290)$} & \multicolumn{2}{|c|}{ Family $(\mathrm{N}=125)$} & \multicolumn{2}{|c|}{ Non Family $(\mathrm{N}=165)$} \\
\hline & 0.888 & $(8.333)^{* * *}$ & 0.515 & $(4.119)^{* * *}$ & 0.895 & $(5.731)^{* * *}$ \\
\hline Firm Leverage & 0.032 & $(2.220)^{* *}$ & -0.016 & $(-0.471)$ & 0.010 & $(0.472)$ \\
\hline Firm Age (years) & 0.004 & $(3.771)^{* * *}$ & 0.0001( & $0.070)$ & 0.006 & $(3.518)^{* * *}$ \\
\hline Firm Size (lnasset) & -0.071 & $(-7.604)^{* * *}$ & -0.022 & $(-2.107)^{* *}$ & -0.082 & $(-5.773)^{* * *}$ \\
\hline BSize & -0.009 & $(-4.885)^{* * *}$ & -0.012 & $(-4.709)^{* * *}$ & -0.011 & $(-4.383)^{* * *}$ \\
\hline OutDir & 0.064 & $(2.371)^{* *}$ & -0.072 & $(-2.489)^{* *}$ & 0.130 & $(2.925)^{* * *}$ \\
\hline Duality & 0.018 & $(0.780)$ & -0.036 & $(-2.280)^{* *}$ & 0.147 & $(1.850)^{*}$ \\
\hline Observation & \multicolumn{2}{|l|}{2030} & \multicolumn{2}{|l|}{875} & \multicolumn{2}{|l|}{1155} \\
\hline $\mathbf{R}^{2}$ & \multicolumn{2}{|l|}{0.542} & \multicolumn{2}{|l|}{0.571} & \multicolumn{2}{|l|}{0.516} \\
\hline Adj. $\mathrm{R}^{2}$ & \multicolumn{2}{|c|}{0.464} & \multicolumn{2}{|l|}{0.496} & \multicolumn{2}{|c|}{0.433} \\
\hline F-stat (p-value) & \multicolumn{2}{|c|}{$6.958(0.000)$} & \multicolumn{2}{|c|}{$7.608(0.000)$} & \multicolumn{2}{|c|}{$6.183(0.000)$} \\
\hline
\end{tabular}

*** Significant at the $1 \%$ level. ** Significant at the $5 \%$ level. * Significant at the $10 \%$ level.

$t$-statistics are in parentheses 